


\title{
The Protracted Civil War in Libya: The Role of Outside Powers
}

\author{
YAHIA H. ZOUBIR \\ KEDGE Business School, France \\ Brookings Doha Center, Qatar \\ ORCID No: 0000-0003-4234-6862
}

ABSTRACT The collapse of the Muammar Qaddafi regime was ostensibly the prelude to a democratic Libya. The 2012 election elicited much optimism. By 2014, the domestic situation had taken an unexpected turn for the worse, resulting in two governments, one in the east and one in the west, each supported by numerous militias. While the civil war has pitted Libyans against Libyans, foreign interventions on behalf of opposite side in the conflict have hindered the end of the civil war. Indisputably, foreign interference had begun well before the civil war; however, the military backing to the protagonists has become more pronounced since 2014. The foreign powers involved in the Libyan conflict aim to fulfill specific interests, some of which deriving from the rivalries between those countries. Unless those foreign powers have achieved their goals in Libya, an end to the civil war anytime soon remains unlikely, occasional ceasefires notwithstanding.

Keywords: Libya, Civil War, Egypt, Turkey, UAE, Russia, France, Libyan National Army, Government of National Accord 


\section{Introduction}

T he 42-year dictatorship in Libya ended in October 2011 with the inhumane assassination of Muammar Qaddafi and massive destruction; it took the Western-backed armed uprising eight months of intensive fighting to defeat Qaddafi's loyalist forces. The fall of the Qaddafi regime was a welcome development for some in the region and in the West because of Libya's often unconventional, antagonistic foreign policies. For the Libyans, who rejected his authoritarian domestic policies, the hope was to see change and a transition to a representative order. However, unlike Tunisia or Egypt, Qaddafi's Jamahiriya did not leave behind a standing army nor a reliable potential force that could bring the necessary stability for a political, let alone democratic transition. The regionalist and tribal nature of Libya and the difficulty of disarming the rebels (dozens of militias) and other groups (Islamist militants), coupled with the lack of viable institutions, have generated unsurmountable challenges to the post-conflict reconstruction of the country. ${ }^{1}$ Already in 2011, it was apparent that, because of the political system and the nature of the social structures, the transition would be uncertain. ${ }^{2}$ The interregnum between 2011 and 2014 had shown a few signs of a promising democratic transition, illustrated by first free elections in 2012; however, numerous domestic and geopolitical factors have kept the collapsed Libyan state in a chaotic situation. Indeed, by
2014, Libya had two governments, each claiming electoral legitimacy and authority over this substantial and potentially rich North African country. Fourth largest in Africa by landmass with a relatively small population of merely 6.2 million, Libya boasts the ninth-largest proven oil reserves $^{3}$ and the $21^{\text {st }}$ natural gas reserves in the world. ${ }^{4}$ Naturally, both domestic forces and foreign powers covet this wealth.

\section{The Role of Foreign Powers in Libya's Destabilization}

The Qaddafi regime had tenuous relations, particularly with the United States $^{5}$ but also with Europe, with its neighbors (Tunisia, Algeria, Egypt, and Chad), and with the Gulf states. However, from 1999 until 2011, the Qaddafi regime seemed to have mended relations with most foes and had even been rehabilitated once it had abandoned the program for the production of weapons of mass destruction in December 2003. Domestically, the regime had shown some signs of change, at least in rhetoric, particularly after 2009 when it sought to craft a new constitution. During that same period, Qaddafi thought that he was beloved by his people and deluded himself about the legitimacy and popularity of his rule. Therefore, the rebellion came as a real surprise to the regime.

Foreign intervention in Qaddafi's Libya occurred in the guise of repeated bombings by the United States and weighty sanctions imposed by the 
U.S. and the United Nations. But the most fateful intervention occurred in 2011. The United Kingdom, France, the United States, and many members of the Arab League, primarily the United Arab Emirates and Saudi Arabia, sought regime change including the removal of Qaddafi himself regardless of the mending of relations that had occurred prior to the uprising. They thus supported the rebellion not only diplomatically but also militarily. In breach of UN resolution 1973, France, the UK, and the United States militarily aided the rebels, sending advisors to assist them in the fight against government troops and the toppling of Qaddafi. Although the insurgents played unquestionably an important role in combating the regime, their fight would have failed had it not been for NATO's special operations forces on the ground targeting for airstrikes, training Libyan rebels, handling the logistics, operating communications and planning as well as organizing and leading the Libyan insurgents in battle. The Central Intelligence Agency (CIA) and British Secret Intelligence (MI6) operatives, too, played a critical role in helping the insurgents. Unquestionably, arming insurgents in the conflict against loyalist forces not only intensified the first civil war but it also dissuaded the insurgents from accepting a negotiated agreement, as was encouraged by the African Union and countries, such as China, Russia, and others, which had opposed NATO’s military intervention.

The successful overthrow of the regime did not mean the end of for-

\section{The successful overthrow}

of the regime did not mean

the end of foreign presence

nor the alliances between

domestic forces and outside

powers

eign presence nor the alliances between domestic forces and outside powers. While NATO bombings had stopped, the chaotic situation that ensued facilitated the presence of the so-called ISIS and other terrorist groups like al-Qaeda in the Islamic Maghreb (AQIM); this in turn served as justification for continued Western intervention in Libya. This time, terrorism and the potential terrorist threat to Europe, as well as illegal migration across the Mediterranean served as the new rationale for this interference. Thus, the United States, whose embassy had been attacked in September 2014 -causing the death of the ambassador and three personnel- began in 2015 to launch airstrikes against ISIS targets. ${ }^{6}$ Italy, which was favorable to military intervention in Libya, had given the United States permission to use Italian airfields to launch armed drone flights over Libya. ${ }^{7}$ In 2018, the U.S. air force launched strikes against AQIM in Libya, killing two notorious militants; ${ }^{8}$ another strike occurred in September 2019 killing eight suspected ISIS combatants. ${ }^{9}$ The United States also sent Special Operations Forces to Libya under the new con- 


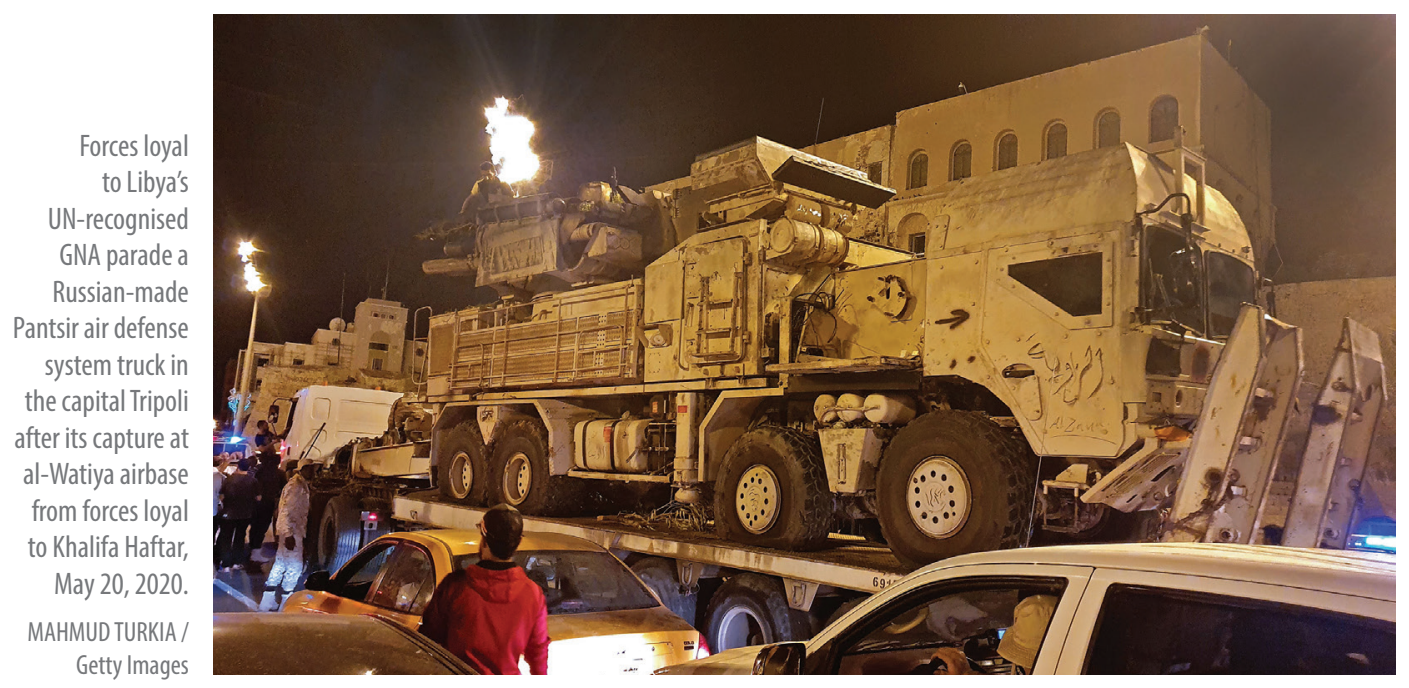

cept of "low visibility operations,"10 which consist ostensibly of helping local forces fight terrorism. The U.S. also established two outposts in Eastern and Western Libya in late 2015. The task of those outposts was to line up local partners ahead of a possible ground attack against ISIS. ${ }^{11}$

The U.S. intervention was comforted not only by the presence of ISIS and other militant groups but also by the domestic ideological battles among Libyans (Muslim Brotherhood, Madkhalists, Salafists, etc.). Indeed, in 2014, renegade self-proclaimed Marshall Khalifa Haftar entered the political scene in Libya; he gathered militias loyal to his vision. In May 2014, they assaulted the bases of other Islamist, Salafist militia groups, such as Ansar al-Sharia or the $17^{\text {th }}$ February Brigade, in Benghazi. ${ }^{12}$ The operation, codenamed, "Operation Dignity [karama]," marked the beginning of the still ongoing second civil war. Haftar's involvement in the
post-Qaddafi crisis exacerbated divisions among Libyans. Not only that, but this also resulted in new alliances between him and foreign powers that supported him for different reasons regardless of the existence of the United Nations-recognized Government of National Accord (GNA) in Tripoli, which emanated from the Libyan Political Agreement (LPA) in 2015. However, the House of Representatives in Tobruk, which has supported Haftar ever since, has refused to recognize the GNA.

In sum, since the uprising of February 2011 against the Qaddafi regime, foreign involvement in the Libyan civil war has not abated; in fact, this involvement has become more prominent, thus hindering the prospects of Libya's national reconciliation and post-reconstruction. An analysis of the roles that various powers have played in Libya demonstrates that the main objectives have been to serve discrete interests whose objective is 
not to end hostilities. In this conflict, foreign powers supported either the GNA, led by Prime Minister Fayez al-Sarraj, or the Libyan National Army (LNA) led by Marshall Khalifa Haftar. Turkey, Qatar, and, to a lesser degree, Italy, have been the GNA's main supporters, while Russia, Egypt, the UAE, Saudi Arabia, Jordan, and France have provided their backing to Haftar, ${ }^{13}$ whose objective all along has been to take full control of Libya -which he could have succeeded in achieving had it not been for Turkey's intervention on behalf of the GNA in early 2020. ${ }^{14}$ This has transformed the Libyan civil war (essentially a struggle for power and resources between locally armed factions) into a proxy war in which the contending Libyan sides rely on foreign military support to offset the other.

\section{Turkey's Interests and Role in Libya}

In April 2019, Haftar began his offensive to capture Tripoli; although it resisted the assault for a while, the GNA did not have any military backing that could halt the advance of Haftar whose troops were well equipped by Russia, Egypt, the UAE, France, and others. The Turkish-supported GNA's counter-offensive proved effective not only in defeating Haftar's troops but also in pushing them eastward to the edges of the strategic city of Sirte, which boasts al-Jufra airbase used by the Russian air force to support Russian mercenaries of the Wagner Group fighting alongside Haftar's LNA. ${ }^{15}$

\section{Before Qaddafi's overthrow,} nearly one hundred Turkish construction companies had contracts in Libya. Because of the 2011 uprising, they had to abandon their projects incomplete, losing $\$ 19$ billion

Undoubtedly, unlike the other powers' involvement in Libya, Turkey's is legitimate simply because the UN-recognized government, GNA, had called on the Turkish government to come to its rescue. France, which had intervened in Mali in 2013 to defend the government against the advance of terrorist groups on the capital Bamako, condemned Turkish intervention in Libya. President Emmanuel Macron, whose government is supporting Haftar, stated that, "We won't tolerate the role that Turkey is playing in Libya." 16 The Arab League, some of whose members are deeply involved in Libya's civil war, condemned Turkey for its use of funded mercenaries from Syria associated to factions close to jihadist terrorism. ${ }^{17}$

Turkey's intervention begs the question as to its interests and objectives there. Undoubtedly, Turkey has geostrategic interests in Libya. Before the crisis in Libya and the latter's direct intervention in 2020, Turkey had, since the 1970s, extensive economic interests in the country; indeed, many Turkish construction companies had been quite active in 


\section{While the fall of Qaddafi}

was a welcome event for the

autocratic regime in Egypt,

the prospect of a Muslim

Brotherhood-inspired

government in Libya has been

unacceptable to Egypt
Libya. According to some reports, from 1972 onward, the contracts that Turkish firms have signed amounted to nearly $\$ 40$ billion in Libya's construction sector. ${ }^{18}$ Before Qaddafi's overthrow, nearly one hundred Turkish construction companies had contracts in Libya. Because of the 2011 uprising, they had to abandon their projects incomplete, losing \$19 billion. ${ }^{19}$ The destructive civil wars (2011, 2014, and 2019) have resulted in massive economic losses. Because of the instability, Libya has failed to pay to Turkey approximately $\$ 15$ billion in unpaid contractual obligations. ${ }^{20}$ The cost of reconstruction is currently estimated at $\$ 50$ billion; obviously, Turkey would like to partake in that post-conflict reconstruction which partly justifies its involvement in the country. However, those economic interests are not limited to investment and participation in rebuilding of the country. Turkey has more important geopolitical and geo-economic interests which explain its support for the GNA. Haftar's involvement in the conflict and the growing support from Turkey's foes, namely, Egypt and the
UAE, on the one hand, and Haftar's decision to seek to conquer Tripoli, on the other hand, prompted Ankara to become more implicated in the conflict. Thus, it decided to increase its military supplies and training to the GNA, making public its support to the GNA. Undoubtedly, Turkey's backing of the GNA aimed to offset the balance in favor of Haftar due to the patronage he received from Egypt, the UAE, Russia and others. But the involvement in Libya pertains to Turkey's broader objectives related to the Eastern Mediterranean, which boasts considerable oil and gas resources.

Indeed, the amount of natural gas available in the Eastern Mediterranean is considerable. In 2010, the United States Geological Survey (USGS) estimated the deposits at 1.7 billion barrels of oil and 3.45 trillion cubic meters of natural gas in the area, ${ }^{21}$ worth $\$ 700$ billion. ${ }^{22} \mathrm{Un}$ doubtedly, Turkey sought, like the neighboring Eastern Mediterranean states to have access to a portion of these deposits, which, clearly, could decide Turkey's geostrategic role in the Eastern Mediterranean. Turkey felt isolated in the region because of the economic zone involving Greece, Cyprus, Israel, and Egypt which was initiated in 2017 the East Mediterranean Energy Forum. That cooperation culminated in the establishment of the East Mediterranean Gas Forum (EMGF) in January 2020. The membership of the EMGF is made up of Egypt, Israel, Greece, Cyprus, Italy, Jordan, and the Palestinian Authority. ${ }^{23}$ As an analyst correctly pointed 
out before the Turkey-Libya agreement of November 2019:

Turkey's provocative action of sending two drilling ships into Cypriot waters to explore for natural gas is a response to a grander provocation coming from the Republic of Cyprus, Greece, Egypt and Israel to exclude Turkey from the marketing of Eastern Mediterranean gas. This common front, composed of interlinked security partnerships among the region's current natural gas producers and Greece, has been increasingly supported by the United States, France and Italy, each of whom has significant economic investments in this gas. For Ankara, its NATO allies' support of this common front is tantamount to a policy of soft containment against Turkey. ${ }^{24}$

There was genuine anxiety among Turkish policymakers which prompted Ankara to sign a memorandum of understanding on Mediterranean maritime sovereignty with the GNA. ${ }^{25}$ One of the objectives was to break the unity of that group. Indeed, after the signing of the agreement, President Erdoğan stated that, "Egypt, Greek Cyprus, Greece and Israel all try at different times to impose their sovereignty over the region in isolation from Turkey," and that the memorandum "has foiled certain conspiracies against [Turkey]." 26 In a speech, Erdoğan emphasized that thanks to the agreements with Libya, "the projects aimed at entirely excluding Turkey from the Mediterranean have thus been wholly thwarted with our recent steps." ${ }^{27}$ Turkey met some of the objectives of the agreement signed with Libya and the drilling in the Eastern Mediterranean: allowing Ankara to break its isolation. ${ }^{28}$

Prior to the agreement with Turkey, the GNA was desperate, especially since neither the Europeans nor the United States had shown any willingness to come to the GNA's rescue. This provided Turkey with an opportunity to secure its position in the Libya chess game and induce Tripoli to align with Ankara. Owing to the deployment of Turkish troops (along with air defense systems and artillery) and air support, the GNA was now able to drive back Haftar's troops compelling them to retreat to the East, ${ }^{29}$ thus compelling Haftar's backers to seek alternatives. Turkey's use of Unmanned Aerial Vehicles (UAV) was extremely successful and turned, without a doubt, the tide of the LNA's offensive.

Beyond the important geopolitical and geo-economic interests, there are also some ideological reasons for Turkey's involvement in Libya. Ankara has apparently coordinated with Qatar to support the Muslim Brotherhood government in Libya; ${ }^{30}$ these attempts are obviously at loggerheads with Egypt, the UAE and Saudi Arabia. ${ }^{31}$ Egypt, in particular, which forcibly removed in 2013 the democratically-elected Muslim Brotherhood government, was incensed with Turkey's support for the GNA. Egypt never forgot that Turkey had been one of the countries that condemned unequivocally the coup, ${ }^{32}$ which until now has poisoned relations between Ankara and Cairo. 


\section{Egypt's Role in the Libyan War}

Egypt has strategic reasons to be involved in Libya. Geographically, the two countries share a 700-mile border. After the passing of President Gamal Abdul-Nassar, relations with Qaddafi, who was imbued with Nasserite and Arab nationalist ideas, soured. While the fall of Qaddafi was a welcome event for the autocratic regime in Egypt, the prospect of a Muslim Brotherhood-inspired government in Libya has been unacceptable to Egypt. Since 2013, Abdel Fattah el-Sisi's Egypt has conducted a resolute, unrelenting battle against Islamism, including the Muslim Brotherhood, which it considers as a terrorist organization. Thus, when Haftar claimed to have come to back to Libya to rid the country of terrorism, Egypt extended its full and steadfast support to him. Like, Haftar, el-Sisi has deep hostility toward Islamist movements; the Egyptian government has thus provided him with military and diplomatic support. ${ }^{33}$ More importantly, Cairo saw in Haftar a man they could use to serve Egypt's economic (obtaining Libyan oil at discounted prices, which Cairo had obtained before, for its ailing economy), ideological (fighting Islamism), and security (protecting borders) interests and to bring about stability to Libya, thus preventing the fallouts from its current instability without having to intervene directly militarily. ${ }^{34}$

Egypt sided with Haftar from the outset because of the close ties that the Libyan branch of the Muslim Brotherhood had established with the GNA and the fear that the branch could launch attacks against Egypt. Thus, Cairo supplied Haftar with weapons in violation of the UN arms embargo on Libya, ${ }^{35}$ and assisted in the renewal of Libya's erstwhile intelligence services to ensure the security of the common border and thwart the penetration of terrorists. Undoubtedly, Egypt (with backing from the UAE, Saudi Arabia, Russia, and France) was hopeful that Haftar would become strong enough and take full control over Libya. Had it not been for Turkey's intervention on behalf of the GNA, this scenario would have certainly materialized. Failure of Haftar to seize Tripoli and his retreat compelled Cairo to seek a diplomatic solution to temporize until Haftar's forces could reorganize. Thus, Egypt announced in June 2020 the Cairo Declaration, which called for a ceasefire. ${ }^{36}$ While the Arab League, dominated by the Gulf countries and their regional allies welcomed the Declaration, the GNA and Turkey rejected it. ${ }^{37}$ As correctly pointed out, the call for withdrawal of all foreign forces from Libya was aimed at Turkey, not at Haftar's supporters. ${ }^{38}$ The Egyptian threat to intervene in Libya ${ }^{39}$-with approval on July 13 from Libya's House of Representatives ${ }^{40}$ - would have resulted in direct conflict between Egyptian and Turkish forces, especially since Egypt also sought support from the Libyan tribes. ${ }^{41}$ Neither the United States nor Russia would have approved of such Egyptian intervention. However, the alliance between el-Sisi and Libya's powerful speaker of parliament, Aguila Saleh, proved 
that Haftar was expendable in Cairo's eyes $^{42}$ and that the defeat he had suffered was not without consequences. Egypt's direct military intervention in Libya would have been a dangerous gamble. ${ }^{43}$ A victory, unlikely, would have strengthened el-Sisi with his patrons (the UAE and Saudi Arabia). An entrapment in Libya, due to the difficulties in logistics, and a defeat on the ground or even a stalemate would delegitimize his presidency and aggravate an already challenging socioeconomic situation in Egypt.

\section{The UAE: Maintaining the Status Quo in MENA Region}

Despite the distance that separates it from Libya, the United Arab Emirates (UAE) has for years intervened in the country. With its gigantic wealth the UAE has provided considerable weaponry to Haftar and has launched many air strikes against the GNA forces. ${ }^{44}$ Abu Dhabi wishes ostensibly to ascertain its regional domination and to suppress any democratic movements and Islamist forces in the Arab world, principally the Muslim Brotherhood. To counter the Muslim Brotherhood, it has sought to increase the influence of Madkhali-Salafism, a very conservative Sunni doctrine that originated in Saudi Arabia. As correctly pointed out, Madhalism has "intolerant actions and anti-democratic agenda. Their presence in powerful armed groups makes them central actors in Libya's conflict. ${ }^{45}$ The UAE has displayed since the Arab uprisings un-
The UAE has also recruited

Sudanese mercenaries to fight

alongside Haftar's forces,

luring them through lucrative

security jobs in the Emirates,

but then dispatching them to

fight in Libya's civil war

relenting determination to prevent the establishment of non-autocratic regimes, using Madkhalism as one of its tools. ${ }^{46}$ This largely explains the support that it has provided, with Saudi financial support, to el-Sisi and Haftar, two autocratic individuals claiming to preserve stability. Because of the financial dependence of these two individuals on outside support, their manipulation by the UAE is made easier. If Russia uses the private armed group purportedly an autonomous force as a stratagem for its actions in Libya, the UAE has used, at least in the beginning of the conflict in 2011, humanitarian aid as justification for its intervention in Libya ${ }^{47}$ Later, the UAE provided military assistance openly and in violation of the United Nations' arms embargo. Haftar admitted that he received weapons from the UAE and so did the pro-Haftar speaker of the House of Representatives in Tobruk. ${ }^{48}$ In 2016, the UAE opened an air base in al-Marj in the Eastern part of Libya. ${ }^{49}$ The UAE has also recruited Sudanese mercenaries to fight alongside Haftar's forces, luring them through lucrative security jobs in the 


\section{The presence of foreign}

forces has exacerbated the

rivalries among outside

powers regardless of the many

conferences, like the one in

Berlin in January 2020
Emirates, but then dispatching them to fight in Libya's civil war. ${ }^{50}$

It seems that the UAE's primary objective is to prevent the emergence of a sovereign and stable Libya because an independent, self-sufficient Libya with its vast hydrocarbons wealth would not only compete with the UAE, but would also threaten its bid to impose its hegemony in the North African region and preserve the type of regime that it favors; in other words, the UAE would repeat what it did in Egypt in 2013, when it, and Saudi Arabia, supported al-Sisi to conduct its coup.

\section{Russia: Securing a Presence in the Mediterranean}

During the 2011 uprising, Moscow's abstention in the United Nations Security Council (UNSC) vote signaled a tacit approval of NATO and other actors' intervention in Libya despite the relatively good ties it had maintained with the Qaddafi regime. One can surmise that among the main reasons for the vote was to avoid alienating the majority of the mem- bers in the Arab League who sought to curtail Qaddafi's power -in reality, to remove him. The other explanation is that UNSC resolution 1973 allowed it to protect Libyans against Qaddafi; the resolution did not intimate regime change, but in fact this is exactly what happened to Moscow's exasperation. Nevertheless, the Kremlin found a way to become a key player in post-Qaddafi's Libya. Regardless of the real reasons, the fall of Qaddafi cost Moscow its ally and a loss of influence; therefore, it has endeavored to make a weighty comeback through playing a role in the post-Qaddafi era and influence the course of events. Moscow's direct role in Libya started in summer 2016 when it asked Haftar to discuss Russian support for his troops to fight ostensibly Islamist extremists in the country. The interest in and motivation to support Haftar's LNA derived from a desire to guarantee that Russia would receive privileged access to Libya's hydrocarbons reserves. To achieve that goal, in 2017, the Russian oil company Rosneft signed a contract on energy with the Libyan National Oil Corporation to help revitalize Libya's oilfields. ${ }^{51}$ Clearly, Russia has economic interests in Libya, some of which it had lost due to the 2011 uprising, and would thus like to regain them.

Fighting global jihadism (al-Qaeda or ISIS) and economic interests are among Russia's main interests in Libya. But, more importantly, yet another salient objective is having an influential presence in the Mediterranean. While it has two bases in Syria and easy stopovers in Egypt, ${ }^{52}$ Mos- 


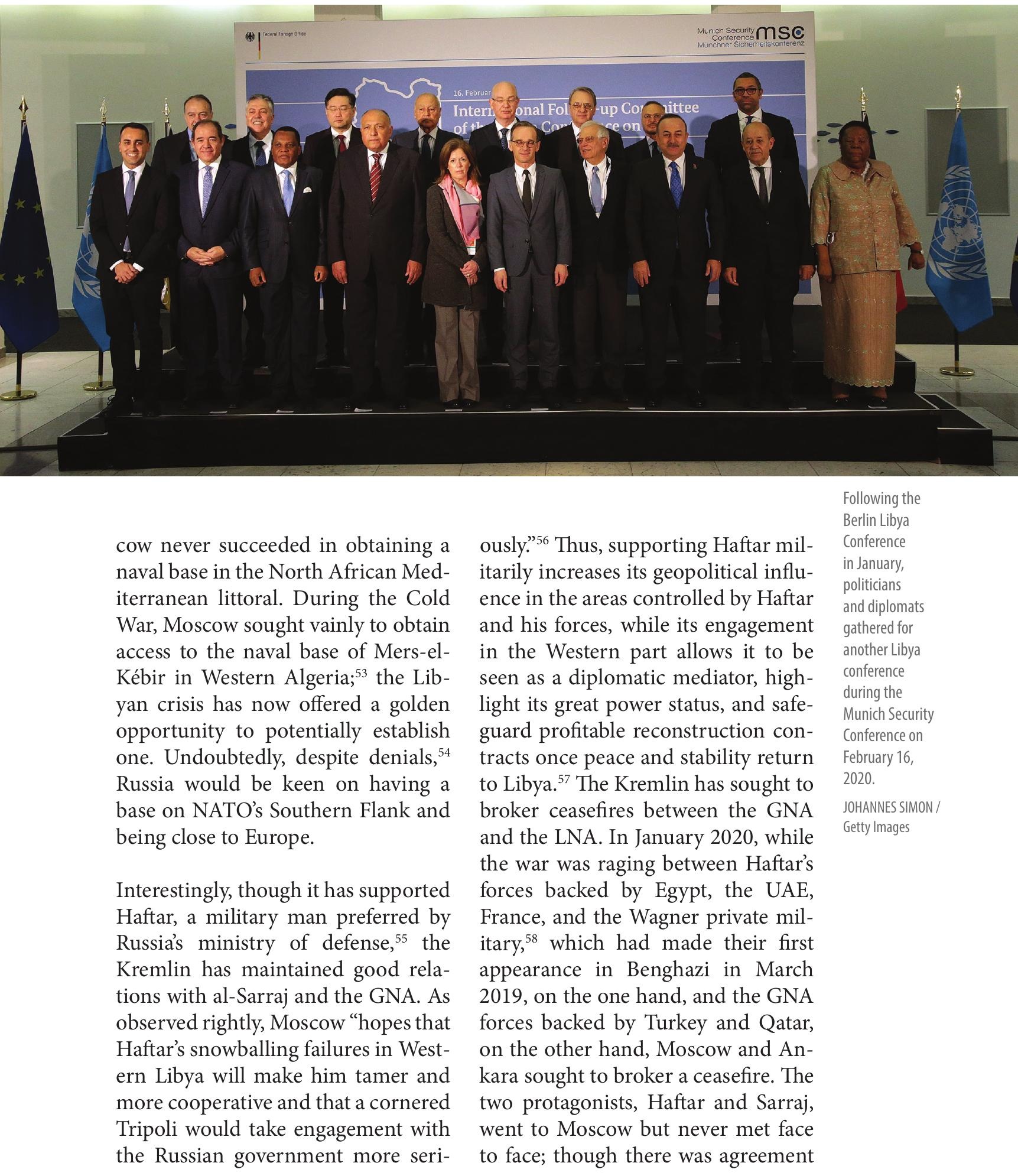


While Southern Mediterranean states worry about an unlikely influx of refugees from Libya, Libya's immediate neighbors, Algeria and Tunisia, which have been neutral in the conflict and offered to mediate between the warring factions, fear incursions of extremist jihadists into their own

territories, intrusions that could destabilize the entire region of its special operations soldiers were killed in the country. This forced the government to admit its military involvement. ${ }^{61}$ Despite its indisputable involvement on behalf of Haftar to whom France supplied weapons both directly ${ }^{62}$ and through the UAE and Egypt -in violation of the arms embargo- it has condemned Turkey's assistance to the GNA in harsh terms. ${ }^{63}$ It also supported Haftar diplomatically; indeed, President Emmanuel Macron invited him to summits, international conferences, and private meetings and welcomed him with all honors due to a head of state.

The obvious question is why France believes it has the right to intervene in Libya on the side of a renegade soldier and condemn the legal Turkish intervention on behalf of a government recognized by the United $\mathrm{Na}$ tions. As correctly pointed out:

French interventionism and interference in domestic Libyan affairs goes [sic] back decades-to the 1940s, when France tried to take and keep control of the southern Libyan province of Fezzan, where it had economic and military interests. Kept at bay by the regime of Moammar Gadhafi for more than forty years, France, in 2011 under President Nicolas Sarkozy, seized the chance offered by the first revolts in Benghazi to recover its long-lost position in Libya by immediately siding with the rebels. ${ }^{64}$

Like Russia, Egypt, and the UAE, France considers that Haftar could serve its interests; thus, it assisted him in all his actions, including his failed 
attempts to seize Tripoli. Haftar's defeat in Western Libya has forced Paris to revise its policy, increasing its rhetoric about finding a political solution. ${ }^{65}$ However, France is perceived as an impediment to peace in Libya $^{66}$ rather than an honest broker in the conflict.

\section{Conclusion}

The Libyan crisis is far from being over. The numerous foreign interventions, the alignments of local militias and their manipulations by foreign powers, the incapacity of the local governments to come to agreement for a peaceful resolution are the main impediment to end the civil war and to initiate a peaceful reconstruction of Libya. The presence of foreign forces has exacerbated the rivalries among outside powers regardless of the many conferences, like the one in Berlin in January 2020.67 The ideological antagonisms (Salafism against Muslim Brotherhood) and geopolitical considerations account for the prolongation of the fratricidal war among Libyans. The conflict threatens to undermine Libya's territorial integrity and sovereignty. Furthermore, while the oil wealth is a blessing that could help Libya rebuild and prosper, it is also a curse because outside forces covet that wealth. As if this was not enough, the population, weary of this long-lasting civil war and suffering from socioeconomic woes, has risen in protest complicating an already unstable situation. Both al-Sarraj (West) and Prime Minister Abdullah al-Thani (East) announced their resignations, decisions which might widen the political vacuum and thus permit greater extremist activity in the country. If this was not enough, the European Union which was divided on Libya (e.g., France against Italy), ${ }^{68}$ has considered options for sending troops to Libya, ostensibly to bolster a ceasefire. ${ }^{69}$ While Southern Mediterranean states worry about an unlikely influx of refugees from Libya, Libya's immediate neighbors, Algeria and Tunisia, which have been neutral in the conflict and offered to mediate between the warring factions, fear incursions of extremist jihadists into their own territories, intrusions that could destabilize the entire region. The irresolution of the conflict will also certainly exacerbate the already volatile situation in the Sahelian neighborhood, particularly, Chad, Niger, and Mali. Thus, resolving the Libyan crisis is crucial to avoid unpredictable, wider regional and international consequences.

\section{Endnotes}

1. For detailed analyses of the Libyan political system under Qaddafi, see, Jacob Mundy, Libya (Cambridge: Polity Press, 2018); Bruce Ronald St. John, Libya: Continuity and Change, Revised edition, (New York: Routledge, 2015).

2. Yahia H. Zoubir and Erzsébet N. Róza, "The End of the Libyan Dictatorship: The Uncertain Transition," Third World Quarterly, Vol. 33, No. 7 (2012), pp. 1267-1283. For a recent account of the role of militias, see, Ulf Laessing, Understanding Libya since Gaddafi, (London: Hurst \& Company, 2020), pp. 37-53.

3. "Libya Oil Reserves," Worldometer, retrieved from https://www.worldometers.info/oil/libya-oil/.

4. "Libya Natural Gas," Worldometer, retrieved from https://www.worldometers.info/gas/libya-natural-gas/. 
5. Yahia H. Zoubir, "The United States and Libya: The Limits of Coercive Diplomacy," Journal of North African Studies, Vol. 16, No. 2 (June 2011), pp. 275-297.

6. "Islamic State Leader in Libya 'Killed in US Airstrike,"' The Guardian, (November 14, 2015), retrieved from https://www.theguardian.com/ world/2015/nov/14/us-airstrike-isis-leader-libya.

7. "Italy Would Consider Any U.S. Request to Use Sicily Air Base for Libya Strikes," Reuters, (August 2, 2016), retrieved from https://www. reuters.com/article/us-libya-security-italy-usaidUSKCN10D1JD.

8. Ryan Browne, "US Conducts First Airstrike against al Qaeda in Libya," CNN, (March 28, 2018), retrieved from https://edition.cnn. com/2018/03/28/politics/us-airstrike-al-qaedalibya/index.html.

9. Ayman Salhi and Ulf Laessing, "U.S. Air Strike Kills Eight Militants in Southern Libya: U.S. military," Reuters, (September 20, 2019), retrieved from https://www.reuters.com/article/amp/idUS KBN1W51O2.

10. Missy Ryan and Sudarsan Raghavan, "US Special Operations Providing Direct, On-theGround Support in Libya," Stars and Stripes, (August 9, 2016), retrieved from https://www. stripes.com/us-special-operations-providingdirect-on-the-ground-support-in-libya 1.4231 48\#: :text=The\%20new\%20American\%20operation\%20in\%20Sirte\%20is\%20the,of\%20the $\% 20$ complexities\%20of\%20political\%20and\%20militia\%20factions.

11. Missy Ryan, "US Establishes Libyan Outposts with Eye Toward Islamic State Offensive," Stars and Stripes, (May 12, 2016), retrieved from https:// www.stripes.com/news/africa/us-establishes-libyan-outposts-with-eye-toward-islamic-state-offensive-1.409346.

12. Chris Stephen, Ian Black, and Spencer Ackerman, "Khalifa Haftar: Renegade General Causing Upheaval in Libya," The Guardian, (May 22, 2014), retrieved from https://www.theguardian.com/ world/2014/may/22/libya-renegade-general-upheaval.

13. Frederic Wehrey, "'Our Hearts Are Dead' After 9 Years of Civil War, Libyans Are Tired of Being Pawns in a Geopolitical Game of Chess," Time, (February 12, 2020), retrieved from https://time. com/5779348/war-libya-global-conflict/.

14. Samuel Ramani, "Turkey's Military Intervention in Libya: A Surprise Triumph for Erdoğan," Royal United Services Institute, Vol. 40, No. 5 (June
2020), retrieved from https://rusi.org/sites/default/files/ramani_web.pdf.

15. "'Dangerous Adventure': Turkey Warns Egypt over Libya Invasion," Al Jazeera, (July 22, 2020), retrieved from https://www.aljazeera.com/news/ 2020/7/22/dangerous-adventure-turkey-warnsegypt-over-libya-invasion.

16. John Irish and Marine Pennetier, "France 'Will Not Tolerate' Turkey's Role in Libya, Macron Says," Reuters, (June 22, 2020), retrieved from https://www.reuters.com/article/us-libya-security-france-turkey-idUSKBN23T2US.

17. Raúl Redondo, "The Arab League Delegitimizes Turkey's Intervention in Libya," Atalayar, (June 24, 2020), retrieved from https://atalayar. com/en/content/arab-league-delegitimizes-turkeys-intervention-libya.

18. "Turkey's Strategic Play in Libya to Help Reap Economic Gains," DW, (July 3, 2020), retrieved from https://www.dw.com/en/turkeysstrategic-play-in-libya-to-help-reap-economicgains/a-54037623.

19. Ezel Sahinkaya, "Why Is Turkey Involved in Libyan Conflict?" Voice of America, (June 4, 2020), retrieved from https://www.voanews.com/extremism-watch/why-turkey-involved-libyan-conflict.

20. "Turkey's Growing Role in Libya: Motives, Background, and Responses," Arab Center for Research and Policy Studies, (January 9, 2020), retrieved from http://arabcenterdc.org/policy_ analyses/turkeys-growing-role-in-libya-motivesbackground-and-responses/.

21. "The Underbelly of Eastern Mediterranean Gas," Journal of Energy Security, (August 13, 2013), retrieved from http://www.ensec.org/index.php? option=com_content\&view=article\&id=445:theunder-belly-of-eastern-mediterranean-gas\&catid=137:issue-content\&|temid=422.

22. Sahinkaya, "Why Is Turkey Involved in Libyan Conflict?"

23. "East Mediterranean States Formally Establish Egypt-based Gas Forum," Reuters, (September 22, 2020), retrieved from https://www.reuters.com/ article/us-mideast-energy-idUSKCN26D14D.

24. Michael Tanchum, "A Dangerous Policy of Turkish Containment in The Eastern Mediterranean," Jerusalem Post, (July 10, 2019), retrieved from https://www.jpost.com/Opinion/A-dangerous-policy-of-Turkish-containment-in-the-Eastern-Mediterranean-595269.

25. "The Libya-Turkey Memorandum of Understanding: Local and Regional Repercussions," 
Libya Tribune, (December 30, 2019), retrieved from https://en.minbarlibya.org/2019/12/30/thelibya-turkey-memorandum-of-understanding-local-and-regional-repercussions/.

26. Cited in, "The Libya-Turkey Memorandum of Understanding: Local and Regional Repercussions."

27. "New Year Message by President Erdoğan," Presidency of the Republic of Turkey, (December 31, 2019), retrieved from https://tccb.gov.tr/en/ speeches-statements/558/114145/new-yearmessage-by-president-erdogan.

28. Murat Yeşiltaş, "Turkey Looks to Libya to Break Its Growing Isolation in the Region," Middle East Eye, (January 6, 2020), retrieved from https:// www.middleeasteye.net/opinion/what-turkeysendgame-libya.

29. Tarek Megerisi, "Geostrategic Dimensions of Libya's Civil War," Africa Security Brief, No. 37 (May 2020), retrieved https://africacenter.org/ wp-content/uploads/2020/05/ASB37EN-Geostrategic-Dimensions-of-Libyas-Civil-War-by-TarekMegerisi.pdf.

30. "Libya: Turkey and Qatar Want to Train Muslim Brotherhood Troops," ANF News, (August 19, 2020), retrieved from https://anfenglish.com/ news/libya-turkey-and-qatar-want-to-train-muslim-brotherhood-troops-46058.

31. Ahmet S. Yayla, “Erdogan's Libyan Adventure: Turkey, Russia, Gas Pipelines and Missiles," The Investigative Journal, (January 13, 2020), retrieved from https://investigativejournal.org/erdoganslibyan-adventure-turkey-russia-gas-pipelinesand-missiles/.

32. Mustafa Akyol, "Turkey Condemns Egypt's Coup," Al-Monitor, (August 21, 2013), retrieved from https://www.al-monitor.com/pulse/originals/2013/08/reasons-turkey-against-egyptcoup.html.

33. Karim Mezran and Arturo Varvelli, "Libyan Crisis: International Actors at Play," in Karim Mezran and Arturo Varvelli (eds.), Foreign Actors in Libya's Crisis, (Washington, DC: The Atlantic Council and ISPI, 2017), retrieved from https://www.ispionline.it/it/pubblicazione/foreign-actors-libyas-crisis-17224, p. 19

34. Tarek Megerisi, "Egypt, Algeria, Tunisia. Neighboring States - Diverging Approaches," in Mezran and Varvelli, Foreign Actors in Libya's Crisis, p. 25.

35. Alessia Melcangi, "A Two-Pronged Egyptian Strategy to Deal with the Libyan Chaos," Institute for International Political Studies, (September 24, 2020), retrieved from https://www.ispionline.it/ en/pubblicazione/two-pronged-egyptian-strategy-deal-libyan-chaos-27488.

36. "Cairo Declaration: Sisi Launches Initiative for a Comprehensive Solution to Libya Conflict," Al-Marsad, (June 6, 2020), retrieved from https:// almarsad.co/en/2020/06/06/cairo-declaration-sisi-launches-initiative-for-a-comprehensive-solution-to-libya-conflict/.

37. "Tripoli Slams Arab League Statement on Foreign Intervention in Libya," The New Arab, (June 24, 2020), retrieved from https://english.alaraby. co.uk/english/news/2020/6/24/tripoli-slams-arab-league-statement-on-libya.

38. Karim Mezran and Alessia Melcangi, "The Cairo Declaration Is a False Resolution to Libya's Conflict," Libya Tribune, (June 15, 2020), retrieved from http://en.minbarlibya.org/2020/06/15/thecairo-declaration-is-a-false-resolution-to-libyas-conflict/.

39. Nora el-Tawil, “Egypt Would Intervene in Libya to Maintain Military Status Quo: FM," Egypt Today, (September 13, 2020), retrieved from https:// www.egypttoday.com/Article/1/91904/Egyptwould-intervene-in-Libya-to-maintain-militarystatus-quo.

40. "Averting an Egyptian Military Intervention in Libya," International Crisis Group, (July 27, 2020), retrieved from https://www.crisisgroup.org/middle-east-north-africa/north-africa/libya/averting-egyptian-military-intervention-libya.

41. "Egypt Seeks Support of Libya Tribes amid Threat of Intervention," Al Jazeera, (August 20, 2020), retrieved from https://www.aljazeera.com/ news/2020/08/20/egypt-seeks-support-of-libyatribes-amid-threat-of-intervention/.

42. Melcangi, "A Two-Proged Egyptian Strategy."

43. "Egypt's Military Limitations: Cairo's Options to Defend Eastern Libya" Foreign Policy Research Institute, (July 13, 2020), retrieved from https:// www.fpri.org/article/2020/07/egypts-military-limitations-cairos-options-to-defend-eastern-libya/.

44. "Russia, UAE Are Operating Land and Air Attacks in Tripoli Battle, Pro-Haftar Pilot Says," Libya Observer, (December 15, 2019), retrieved from https://www.libyaobserver.ly/news/russia-uaeare-operating-land-and-air-attacks-tripoli-battlepro-haftar-pilot-says.

45. "Addressing the Rise of Libya's Madkhali-Salafis," International Crisis Group, Report No. 20, (April 25, 2019), https://www.crisisgroup.org/middleeast-north-africa/north-africa/libya/addressing-rise-libyas-madkhali-salafis; see, also, Fred- 
eric Wehry, "Salafism and Libya's State Collapse: The Case of the Madkhalis," Carnegie Endowment for International Peace, (December 19, 2019), retrieved from https://carnegieendowment.org/ 2019/12/19/salafism-and-libya-s-state-collapsecase-of-madkhalis-pub-81835.

46. The Madkhalists were also present in neighboring Algeria, whose security forces has contained their spread and influence in the country. R. Mahmoudi, "Salafistes 'madkhalistes' et Frères musulmans algériens s'entredéchirent," [Madkhalist Salafists and Algerian Muslim Brotherhood tear each other apart] Algérie Patriotique, June 10, 2018, retrieved from https://www.algeriepatriotique.com/2018/06/10/salafistes-madkhalistesfreres-musulmans-algeriens-sentredechirent/.

47. "UAE's Libya Role 'Confined to Humanitarian Aid,"' Gulf News, (March 21, 2011), retrieved from https://gulfnews.com/uae/government/uaes-libya-role-confined-to-humanitarian-aid-1.780546 .

48. "UAE Provided Military Aid for Haftar, Says Libyan Politician," Middle East Eye, (April 27, 2017), retrieved from https://www.middleeasteye.net/ $\mathrm{fr} /$ news/uae-provided-military-support-haftarsays-libyan-politician-1056112839.

49. "UAE Establishes Military Base in Eastern Libya with France's Assistance to Give Haftar's Forces a Hand," Libyan Observer, (November 1, 2016), retrieved from https://www.libyaobserver.ly/news/ uae-establishes-military-base-eastern-libya-frances-assistance-give-haftars-forces-hand.

50. "UAE Establishes Military Base in Eastern Libya with France's Assistance to Give Haftar's Forces a Hand."

51. "Russia Increases Involvement in Libya by Signing Oil Deal," The Guardian, (February 21, 2017), retrieved from https://www.theguardian. com/world/2017/feb/21/russia-increases-involvement-libya-signing-oil-deal-rosneft.

52. Alain Rodier, "Et maintenant, la Libye: la Russie Avance un Nouveau Pion pour Son Retour en Force en Méditerranée" [And Now, Libya: Russia Advances a New Pawn for its Return in Force in the Mediterranean Sea], Atlantico, (January 27, 2017), retrieved from https://www.atlantico.fr/ decryptage/2943569/et-maintenant-la-libye-la-russie-avance-un-nouveau-pion-pour-son-retour-en-force-en-mediterranee.

53. Yahia H. Zoubir, "Soviet Policy in the Maghreb," Arab Studies Quarterly, Vol. 9, No. 4 (Fall 1987), pp. 399-421.

54. "Russia's Plans for Military Base in East Libya: Truth or Fabrication," Libya Observer, (January 14,
2018), retrieved from https://www.libyaobserver. ly/news/russias-plans-military-base-east-libyatruth-or-fabrication.

55. Yury Barmin, "Russia's Endgame in Libya," $A$ l Jazeera, (July 11, 2019), retrieved from https:// www.aljazeera.com/indepth/opinion/russiastrategy-libya-190710070457901.html.

56. Barmin, "Russia's Endgame in Libya."

57. Samuel Ramani, "Russia's Strategy in Libya," Royal United Services Institute, (April 7, 2020), retrieved from https://rusi.org/commentary/russias-strategy-libya.

58. On the role of the Wagner group in the Libyan war, see, Salem Solomon, "Russian Mercenaries in Libya Leave Mines as Deadly Calling Cards, Observers Say," Voice of America, (August 4, 2020), retrieved from https://www.voanews.com/middleeast/russian-mercenaries-libya-leave-minesdeadly-calling-cards-observers-say.

59. Anna Malpas and Imed Lamloum, "Libyan Strongman Delays Signing Ceasefire at Moscow Talks," AFP, (January 14, 2020), retrieved from https://news.yahoo.com/libyan-rivals-signceasefire-deal-moscow-020343335.html.

60. Mattia Toaldo, "Europe: Carving out a New Role," in Mezran and Varvelli, Foreign Actors in Libya's Crisis, pp. 59-67.

61. "France Admits Special Forces Soldiers Killed in Libya," Radio France International, (July 20, 2016), retrieved from https://www.rfi.fr/en/africa/ 20160720-france-admits-special-forces-solcierskilled-libya.

62. Paul Taylor, "France's Double Game in Libya," Politico, (April 17, 2019), retrieved from https:// www.politico.eu/article/frances-double-gamein-libya-nato-un-khalifa-haftar/.

63. Steve Tenré, "Emmanuel Macron Dénonce Le 'Jeu Dangereux' de La Turquie en Libye [Emmanuel Macron Denounces Turkey's Dangerous Game' In Libya]," Le Figaro, (June 22, 2020), retrieved from https://www.lefigaro.fr/flash-actu/ emmanuel-macron-denonce-le-jeu-dangereuxde-la-turquie-en-libye-20200622; see also, Nathalie Loiseau, "Turkey and the West: With Friends Like These," Atlantic Council, (July 13, 2020), retrieved from https://www.atlanticcouncil.org/ commentary/op-ed/turkey-and-the-west-withfriends-like-these/.

64. Karim Mezran and Federica Saini Fasanotti, "France Must Recognize Its Role in Libya's Plight," The Atlanticist, (July 21, 2020), retrieved from https://www.atlanticcouncil.org/blogs/new-at- 
lanticist/france-must-recognize-its-role-in-libyasplight/.

65. Ismaeel Naar and Omar Elkatouri, "French vs Italian Support to Libyan Rival Sides Depends On Vital Interests: Expert," Al Arabiya English, (June 25, 2020), retrieved from https://english. alarabiya.net/en/News/north-africa/2020/06/25/ French-vs-Italian-support-to-Libyan-rival-sidesdepends-on-vital-interests-Expert.

66. "Crise En Libye: Comment La France Fait Obstacle a La Paix [Crisis in Libya: How France Impedes Peace], "France24, (July 14, 2020), retrieved from https://www.fr24news.com/fr/a/2020/07/ crise-en-libye-comment-la-france-fait-obstaclea-la-paix.html.
67. German Government, "The Berlin Conference on Libya: Conference Conclusions," Press release 31, (January 19, 2020), retrieved from https:// www.bundesregierung.de/breg-en/news/theberlin-conference-on-libya-1713882.

68. "Divided Europe: How the West Lost Influence in Libya's War," Alaraby, (July 24, 2020), retrieved from https://english.alaraby.co.uk/english/indepth/2020/7/24/how-the-west-lost-influencein-libyas-war.

69. Jacopo Barigazzi, "EU Draws Up Options for Boots on The Ground in Libya," Politico, (October 1, 2020), retrieved from https://www.politico. eu/article/eu-libya-military-options-ceasefire/ amp/. 


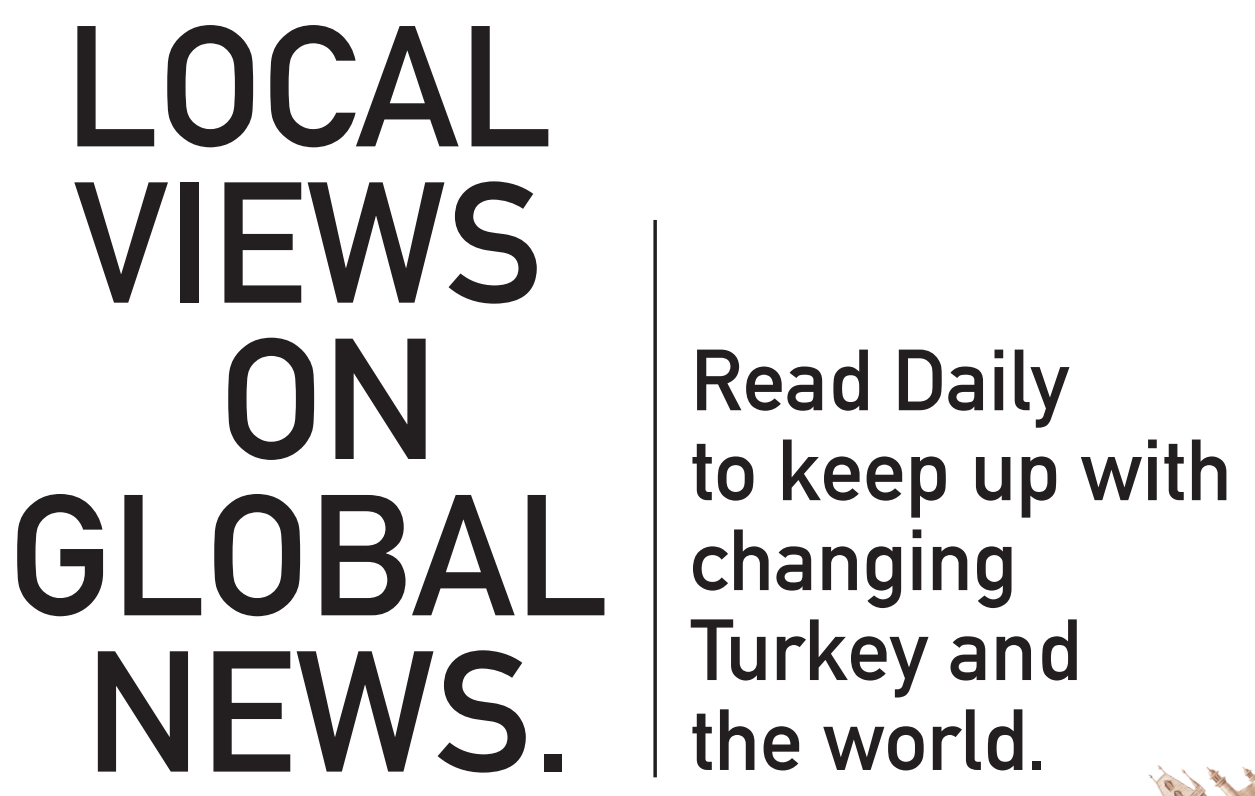

Read Daily to keep up with changing Turkey and the world.

\section{DAILY 马AВAH}

